\title{
Selective browsing behaviour of ungulates influences the growth of Abies alba differently depending on forest type
}

\author{
Andrea Doris Kupferschmid ${ }^{1}$ \\ ${ }^{1}$ Swiss Federal Institute for Forest, Snow and Landscape Research WSL, Zürcherstrasse 111, 8903 \\ Birmensdorf, Switzerland, andrea.kupferschmid@wsl.ch
}

https://doi.org/10.1016/j.foreco.2018.06.046

\section{Highlights}

- Browsing only buds vs. a large part of the annual leader shoot was crucial.

- Within-tree browsing intensity on Abies alba saplings was lower in Fagus-dominated forests.

- Due to selective browsing, lightly browsed saplings grew better than unbrowsed ones.

- Strong browsing on leader shoots contributes to shifts in the species' growth ranking.

- Surveying within-tree browsing intensity is recommended to accurately estimate browsing impacts.

\begin{abstract}
Ungulate densities and browsing have increased over the past decades in many forests in Europe. Browsing on tree saplings is a selective process dependent on forest type. This study tested whether the impacts of browsing are altered by differences in tree vigour and within-tree browsing intensity (browsing only buds vs. browsing a large part of the annual leader shoot), and if these effects are modulated by forest type.
\end{abstract}

The growth rate and within-tree browsing intensity of leader shoots were investigated for different height classes and species compositions at 18 sites (each with 14-64 plots) in spring before budburst and at 6 sites in autumn. The sites were situated in northeast Switzerland and comprised four major forest types that had Abies alba regeneration. Linear mixed-effects models were fitted for the relative growth rate of Abies and for the ratio of the relative growth rate of Abies to the relative growth rate of Picea abies.

More Abies saplings were present in Fagus-dominated forests than in Fagus-Abies or Picea-Abies forests, and within-tree browsing intensity on their leader shoots was lower. Lightly browsed Abies saplings grew better than those that were not browsed, which in turn grew better than strongly browsed saplings. This pattern, which occurred irrespective of forest type, was caused by selective browsing on vigorously growing trees and led to a greater impact of strong browsing in comparison to light browsing on the growth of Abies saplings.

The ratio of the relative growth rate of Abies to Picea was altered by within-tree browsing intensity, forest type and soil depth. Generally, this ratio was highest in shallow soiled Fagus-dominated forests after light browsing and lowest in Fagus-Abies forests after strong leader shoot browsing, indicating a browsing-induced shift in the relative difference in growth rate between species towards Picea in Fagus-Abies and Picea-Abies forests but not in Fagus-dominated forests.

Because the main factor influencing the growth of Abies saplings was the amount of tissue loss on the leader shoots (bud vs. entire or large parts of leader shoots), browsing inventories neglecting to assess the within-tree browsing intensity are not recommended. The within-tree browsing intensity of leader shoots is a simple but objective measurement that should be used in forest regeneration inventories of Abies for improving estimates of the impact of ungulate browsing.

This document is the accepted manuscript version of the following article:

Kupferschmid, A.D. (2018). Selective browsing behaviour of ungulates influences the growth of Abies alba differently

depending on forest type. Forest Ecology and Management, 429, 317-326. https://doi.org/10.1016/j.foreco.2018.06.046 1

This manuscript version is made available under the CC-BY-NC-ND 4.0 license http://creativecommons.org/licenses/by-nc$\mathrm{nd} / 4.0$ 


\section{Keywords}

forest inventory, growth rate, herbivory, silver fir, tree regeneration, ungulate browsing

\section{Introduction}

Large mammalian herbivores depend on plant communities for their existence. Leaves, shoots and bark of tree saplings are part of the normal diet of ungulate species such as red deer (Cervus elaphus L.), roe deer (Capreolus capreolus L.) and chamois (Rupicapra rupicapra L.) (Cornelis et al., 1999; Tixier et al., 1997). However, it is known that ungulates browse selectively on particular tree species (Boulanger et al., 2009; Coté et al., 2004). For example, European silver fir (Abies alba Mill.) has been identified as one of the most selected species, while Norway spruce (Picea abies L.) is usually one of the least selected species in Europe (e.g. Gill, 1992a; Kupferschmid et al., 2015a). In addition, tree species differ in their tolerance to browsing (Kupferschmid, 2017). Browsing may thus lead to shifts in the relative rates of growth of different tree species, which can in turn result in changes in the relative abundance of different tree species that successfully regenerate (e.g. Gill and Beardall, 2001; Krueger et al., 2009). Several empirical (Augustine and McNaughton, 1998) and modelling studies (Didion et al., 2009; Didion et al., 2011) have shown that selective browsing can affect the development of a forest stand and cause major changes in plant community composition and structure. For the example of fir and spruce, under continuously high browsing pressure, fir-spruce forests are expected to become spruce forests (Kupferschmid and Brang, 2010; Tremblay et al., 2007).

Feeding selectivity of herbivores is not limited to the degree to which different plant species suffer tissue loss, as it also includes selectivity among individual trees of the same species. At the local scale, a single ungulate selects food items by choosing among tree species, individual trees (e.g. according to tree height or vigour) and parts of trees (forage quality), and it additionally decides how much biomass to remove (forage quantity). Generally, there seems to be a connection between individual plant morphology and feeding behaviour (e.g. Hartley et al., 1997). Larger saplings with a large crown volume have been found to be more likely to be browsed by ungulates (lason et al., 1996; Kupferschmid et al., 2015b). Moreover, a close relationship between shoot size and bite size has been reported (Danell et al., 1994; Shipley et al., 1999). Thus, herbivore species probably feed selectively on vigorously growing plants or plant parts, as suggested by the plant vigour hypothesis (Price, 1991). However, in a study in Swiss (fir-) beech forests, vigorously growing Abies alba saplings remained larger even after browsing (Kupferschmid et al., 2013). Therefore, the role of individual tree selection and forage quantity on the growth-rate ranking of different tree species remains unclear.

Site characteristics like soil pH and depth, as well as forest stand basal area, type and developmental stage, influence the availability of resources such as nutrients, water and light. This resource availability affects i) the forage availability (tree saplings and ground vegetation) and thus ungulate selection (Cornelis et al., 1999), ii) the growth rate of tree saplings (e.g. Vandenberghe et al., 2008) and iii) the ability of trees to react to browsing (i.e. 'stress status hypothesis', see Kupferschmid, 2017). In addition, by browsing different parts and numbers of tree saplings, herbivores can alter the resource that limits a plant's fitness and thus its tolerance to herbivory (i.e. 'limiting resource model', see Wise and Abrahamson, 2005). Therefore, it is important to understand interactions between site characteristics and ungulate browsing.

Kupferschmid et al. (2015b) proposed, based on their experiment, that within-tree browsing intensity - i.e. the amount of tissue ungulates eat, such as leader buds only (decapitation), part(s) of the annual leader shoot, the entire annual leader shoot, or much more than just the annual leader shoot - should be integrated into assessments of browsing in order to better estimate the browsing 
impact at different sites. In this study, I tested a simple and quick approach involving measurements of within-tree browsing intensity and tree vigour in forest inventories to address browsing impact more effectively than is possible when only the proportion of browsed trees is assessed. My specific questions were:

- Does within-tree browsing intensity influence the growth rate of Abies alba saplings?

- Does within-tree browsing intensity influence the ratio of the relative growth rate of Abies alba saplings to the relative growth rate of Picea abies saplings and thus lead to shifts in the species' growth ranking?

- Are there interactions between within-tree browsing intensity and site characteristics like forest type, soil pH, soil depth and forest stand basal area and/or developmental stage?

\section{Materials and methods}

Study sites

In order to investigate the influence of ungulate browsing on tree saplings on a regular basis, indicator areas (Rüegg and Nigg, 2003) or sites with surveys of juvenile growth and damage in forests (Amt für Wald Graubünden, 2005) have been established and repeatedly monitored in the cantons of St. Gallen and Grisons in Switzerland. Such sites typically comprise a continuous forest area with different forest developmental stages and forest types. Each site contains a rectangular grid with a fixed grid size of $100 \mathrm{~m}$ between the circular sampling plots, resulting in 14-64 plots per site. The plot centres are permanently marked.

For this study, 17 sites in St. Gallen and 7 in the adjacent north-western part of Grisons were selected on a purposive basis (Table 1). Sites were selected that i) had seed-producing Abies alba trees in the canopy (at least $5 \%$ of canopy trees) and ii) contained at least some sampling plots where Abies alba saplings were present. Once a site was selected, all plots of the site were visited. This resulted in a total of 535 plots with very different densities of saplings (0.01-8.98 Abies alba saplings per $\mathrm{m}^{2}$ ) and browsing intensities (0-92\%; Table 1). 
Table 1: Details of the 24 assessed sites in the two Swiss (CH) cantons St. Gallen (SG) and Grisons (GR), including coordinates; the prevailing forest types at each site (Acer-Fraxinus-Tilia, Fagus, Fagus-Abies and Abies-Picea); the number of chamois (Cham) and red deer (Red) present in relation to the number of roe deer ( $n=n o, f=$ few $<5 \%, m=$ many $>5 \%$ ); the density (Dens); and the proportion of leader browsing (PLB) found in the year 2014 by means of repeated assessments in the St. Gallen indicator areas or through measurements in circles of $2 \mathrm{~m}$ radius in 2016 and 2017; the year and period of the field assessment; soil $\mathrm{pH}$ and depth; hill slope; forest stand basal area; range in elevation above sea level (EL); number of plots assessed; and number of $A b i e s$ saplings and of Abies/Picea pairs that were measured via the nearest tree method.

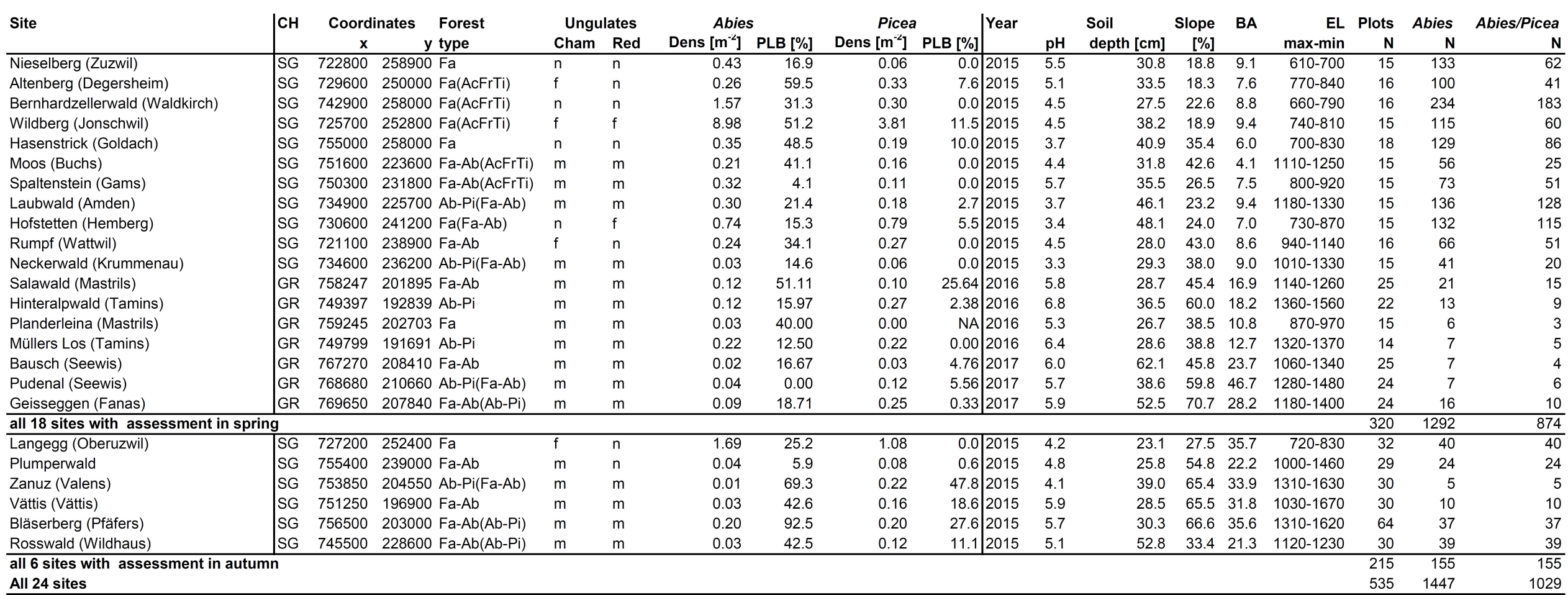




\section{Data collection}

In spring 2015 (11 sites), 2016 (4 sites) and 2017 (3 sites), before budburst, the five (2015 assessment) or two (2016 and 2017 assessments) trees nearest to the plot centre of every height class (hc1: 10-40 cm, hc2: 41-70 cm, hc3: $71-100 \mathrm{~cm}$ and hc4: 101-130 cm) and every species were assessed. The maximal search distance from the plot centre was $10 \mathrm{~m}$ and the measured distance to the saplings was noted in order to calculate sapling density (for details of nearest tree method see Kleinn et al., 2009). The current tree height and the length of the annual increment of the leader shoot formed in the previous year were measured. In cases where the leader shoot was browsed, the remaining part of the annual increment of the leader shoot was measured instead. The within-tree browsing intensity on the leader shoot formed in the previous year was classified into not browsed, lightly browsed (only removal of bud), strongly browsed (loss of a large part of the annual increment), or no leader shoot in that year (owing to older damage).

As summer browsing was sometimes hard to detect, in particular for deciduous trees, on six sites the assessment of the nearest two trees took place in autumn 2015. Therefore, the length of the annual leader shoot formed in 2015 was measured and within-tree browsing intensity was noted for winter 2014/2015 and for summer 2015. As very few saplings of Abies alba were browsed in summer (and were thus omitted from the analysis), this assessment serves as a measure of recovery after different within-tree browsing intensities.

In order to evaluate factors that may influence the frequency of browsing and tree regeneration, the monitoring was complemented with measurements of the stand basal area $\left[\mathrm{m}^{2} / \mathrm{ha}\right.$ ] of living trees (quantified using angle count sampling with a counting factor of 4 (Bitterlich, 1984)); hill slope [\%]; stand developmental stage [young growth and thicket (1), polewood (2), dominated by small timber trees (3), dominated by medium timber trees (4), dominated by large timber trees (5) or mixed stages (6)]; approximate soil depth ([cm], measured in 5 places within the plot with a hand soil driller); $\mathrm{pH}$ of soil A-horizon (potentiometrically determined in the lab with $10 \mathrm{mM} \mathrm{CaCl}$, soil: solution ratio $=1: 2$, equilibration time $30 \mathrm{~min}$ ); and forest type. The four forest types were defined by the dominant tree species in the canopy, i.e. the 'Acer-Fraxinus-Tilia' type was dominated by Acer pseudoplatanus, A. platanoides, Fraxinus excelsior, Tilia cordata, and/or T. platyphyllos, the 'Fagus' type by Fagus sylvatica, the 'Fagus-Abies' type by Fagus sylvatica and Abies alba, and the 'AbiesPicea' type by Abies alba and Picea abies).

\section{Statistical analysis}

The relative growth rate of each sapling was calculated by dividing the length of the intact part of the annual leader shoot (only the remaining part of the shoot in the case of winter browsing) by tree height. For each plot and tree height class, the ratio of the relative growth rate of Abies alba to the relative growth rate of unbrowsed Picea abies saplings was derived from the nearest trees to the plot centres and, if available, the second- up to the fifth-nearest neighbouring Abies and Picea saplings. Picea abies was chosen for this tree-by-tree comparison of species effects rather than Fagus, Acer, Fraxinus or other tree species because i) Picea saplings were available in all forests types and ii) determining the leader axis and measuring leader shoot length is comparable for Picea and Abies saplings.

Abies sapling density was calculated for each plot that contained Abies saplings by means of the plot radius based on the distance of the nearest Abies sapling (dist ${ }_{1}$ ) plus half of the distance to the second nearest Abies sapling (dist 2 , i.e. $r=$ dist $_{1}+0.5^{*}\left(\right.$ dist $_{2}$-dist $\left.{ }_{1}\right)$, (Kleinn et al., 2009)). Abies saplings that did not form a leader shoot (within-tree browsing intensity = 'no leader shoot in that year') or with summer browsing in 2015 were excluded from the statistical analysis owing to low sample size. The analysis was carried out separately for the spring (18 sites) and autumn (6 sites) assessments. 
Linear mixed-effects models were fitted for the relative growth rate of Abies, for the ratio of the relative growth rate of Abies to the relative growth rate of Picea, and for the Abies sapling density in plots containing Abies saplings. Fixed effects included in the model were forest type (either the four individual types, or coniferous vs. deciduous forest), stand developmental stage, hill slope, soil depth, soil $\mathrm{pH}$, stand basal area and leader shoot browsing (either within-tree browsing intensity or presence/absence). Site was included as a random effect. Interactions between the fixed effects were also tested, in particular those involving within-tree browsing intensity. For the ratio of the relative growth rate of Abies to Picea saplings, the interaction between forest type and within-tree browsing intensity was integrated into the statistical model as one factor owning 10 levels, owing to an insufficient number of browsed saplings in the Acer-Fraxinus-Tilia forest type (4 forest types * 3 within-tree browsing intensity levels minus the two Acer-Fraxinus-Tilia levels).

All statistical analyses were completed with $R$ version 3.3.2 (R Core Team, 2016), using the package Ime4 (Bates et al., 2015) with the function Imer. The target variables were transformed using the natural logarithm, except for the relative growth rate of Abies, which was square-root transformed. Variables and interactions with non-significant effects were removed from the model. The best candidate models were selected by using likelihood ratio tests (function anova) for differentiation of the models or, in case of unequal N, the lowest Akaike's information criterion (AIC approach, as in Stauffer, 2008). When a factor had a significant effect and was thus retained in the selected models, a pairwise comparison between the categories was performed (using a pairwise t-test).

\section{Results}

In the 24 sites, 535 plots were assessed, leading to a sample size of 1447 Abies alba saplings and 1029 pairs of Abies and Picea saplings (Table 1). Although 51\% of all plots were situated in sites dominated by forests with Fagus-Abies associations, Abies saplings were found, on average, in only $10.4 \%$ (median; $25 \mathrm{Q}=6.5 \%, 75 \mathrm{Q}=19.2 \%$ ) of the possible plot-height class strata, and Abies-Picea pairs were found in only $7.9 \%(4.9,16.0 \%)$ of the cases. Similarly, in sites dominated by forests with Abies-Picea associations (21\% of all plots), only $6.8 \%$ (3.3\%, $21.6 \%)$ of the assessed plot-height class strata included Abies saplings and $4.8 \%(2.9 \%, 15.7 \%)$ had Abies-Picea pairs). In contrast, only $28 \%$ of the plots were situated in sites dominated by forests with Fagus associations, but $37.1 \%(19.5 \%$, 44.3\%) of the possible plot-height class strata included Abies saplings and $20.3 \%$ (13.5\%, 34.7\%) included Abies-Picea pairs. This finding was mainly due to i) plots without any Abies regeneration and ii) plots without Abies saplings in the taller height classes in sites dominated by Fagus-Abies and Abies-Picea forests (apart from site Laubwald; Table 1). As a consequence, a separate analysis was not undertaken for each of the four height classes.

Abies alba saplings were significantly more frequent in plots that contained Abies regeneration when situated in Fagus forests than when in the other three forest types (Fig. 1a, Tables 2 and 3). Abies density was also higher when the Abies saplings nearest to the plot centre were only lightly browsed compared with plots where the saplings were unbrowsed or strongly browsed (Fig. 1b). In addition to effects of forest type and within-tree browsing intensity, soil pH had a negative and hill slope a positive effect on Abies alba sapling density in plots that contained Abies regeneration (Table 3). Stand developmental stage also had an effect on the Abies density when Abies saplings were present (Table 3), in that stands with large timber trees contained more Abies saplings than types 2-4 and stands with mixed stages, and these more than young growth and thickets (Supplementary Material Fig. S1). 
Table 2: Statistical results of main models for Abies sapling density, the relative growth rate of $A$ bies saplings and the ratio of the relative growth rate of $A b i e s$ alba saplings to the relative growth rate of unbrowsed Picea abies saplings of the same height class from the same plot. Akaike's information criterion (AIC) and $P$ values $(P)$ of the likelihood ratio tests $(. \leq 0.1, * P \leq 0.05, * * P \leq 0.01, * * * P \leq 0.001)$ for the full models (but excluding all interactions), the full models without the listed variable, and the selected models are given. In the last two lines, degrees of freedom (DF) and $P$ values are relative to the selected models in order to indicate the importance of within-tree browsing intensity. Details of the selected models are given in Table 3.

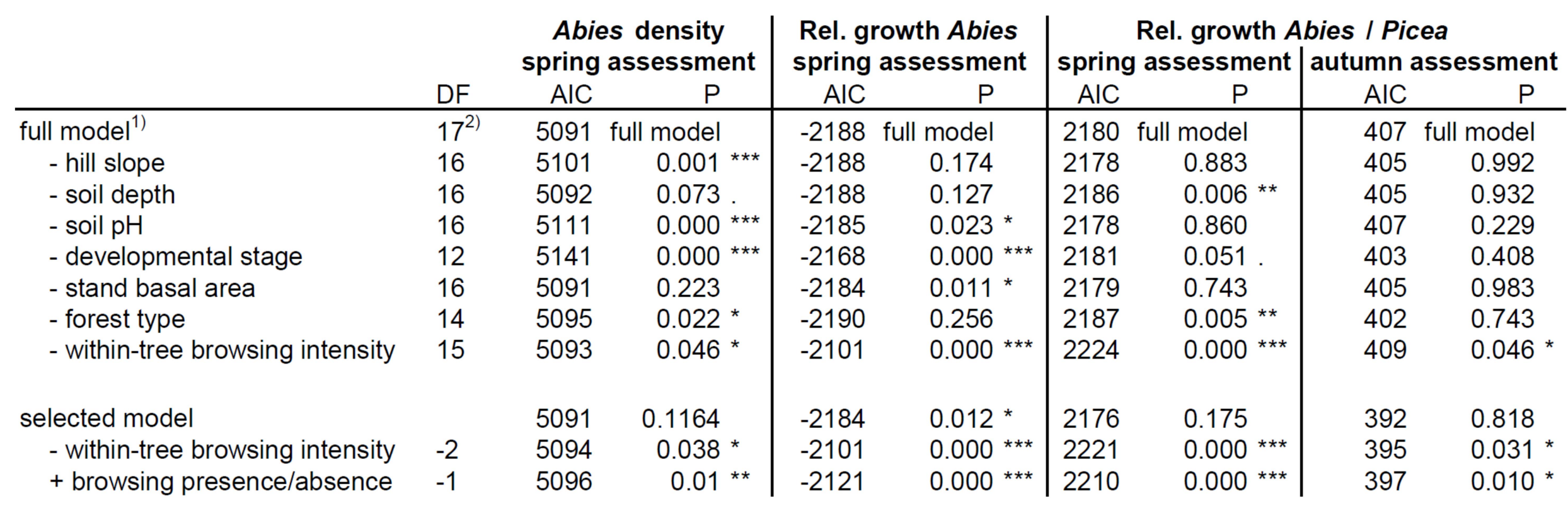

\footnotetext{
1 full model: within-tree browsing intensity + forest type + basal area + developmental stage + soil pH + soil depth + hill slope + (1 | site $)$
}

2 Developmental stage 3 (i.e. small timber) did not occour in the sites with autumn assessment, resulting in DF = 16 
Table 3: Statistical results of the selected models. For the fixed variables included in the selected models, the estimated coefficients \pm 1 standard error and $t$ values are indicated. Abies sapling density data and the ratio of the relative growth rate of Abies alba saplings to the relative growth rate of unbrowsed Picea abies saplings of the same height class from the same plot were transformed by natural logarithm, whereas the relative growth rate of $A b i e s$ saplings was square-root transformed. Site was included as a random effect. The corresponding Akaike's information criterion (AIC) for each model is given in Table 2).

\begin{tabular}{|c|c|c|c|c|c|c|c|c|c|c|c|c|c|}
\hline \multirow{2}{*}{\multicolumn{2}{|c|}{ Selected models }} & \multirow{2}{*}{\multicolumn{3}{|c|}{$\begin{array}{c}\text { Abies density } \\
\text { spring assessment }\end{array}$}} & \multirow{2}{*}{\multicolumn{3}{|c|}{$\begin{array}{l}\text { Rel. growth Abies } \\
\text { spring assessment }\end{array}$}} & \multicolumn{6}{|c|}{ Rel. growth Abies / Picea } \\
\hline & & & & & & & & \multicolumn{3}{|c|}{ spring assessment } & \multicolumn{3}{|c|}{ autumn assessment } \\
\hline random effects: & & Variance & Std.Dev. & & Variance & Std.Dev. & & Variance & Std.Dev. & & Variance & Std.Dev. & \\
\hline site & & 1.349 & 1.162 & & 0.002 & 0.042 & & 0.031 & 0.175 & & $3.20 \mathrm{E}-16$ & 1.79E-08 & \\
\hline residuals & & 2.821 & 1.679 & & 0.010 & 0.099 & & 0.678 & 0.824 & & 0.6883 & 0.8296 & \\
\hline fixed effects: & & Coef. & Std. error & $\mathrm{t}$ value & Coef. & Std. error & t value & Coef. & Std. error & $\mathrm{t}$ value & Coef. & Std. error & $\mathrm{t}$ value \\
\hline intercept & & -1.762 & 0.488 & -3.61 & 0.320 & 0.014 & 23.59 & 0.981 & 0.177 & 5.55 & 0.051 & 0.075 & 0.69 \\
\hline \multirow[t]{2}{*}{ within-tree browsing intensity } & light & 0.328 & 0.176 & 1.87 & 0.015 & 0.010 & 1.45 & 0.164 & 0.110 & 1.49 & 0.302 & 0.227 & 1.33 \\
\hline & strong & -0.260 & 0.165 & -1.58 & -0.105 & 0.011 & -9.25 & -0.747 & 0.110 & -6.80 & -0.458 & 0.215 & -2.14 \\
\hline \multirow[t]{3}{*}{ forest type } & Fagus & 0.782 & 0.245 & 3.19 & & & & -0.352 & 0.142 & -2.47 & & & \\
\hline & Fagus-Abies & 0.001 & 0.311 & 0.01 & & & & -0.556 & 0.158 & -3.53 & & & \\
\hline & Abies-Picea & 0.073 & 0.386 & 0.19 & & & & -0.384 & 0.178 & -2.16 & & & \\
\hline \multicolumn{14}{|l|}{ stand basal area } \\
\hline \multirow[t]{5}{*}{ stand developmental stage } & polewood & -0.139 & 0.182 & -0.76 & 0.010 & 0.011 & 0.90 & & & & & & \\
\hline & small timber & -0.442 & 0.242 & -1.83 & 0.001 & 0.014 & 0.05 & & & & & & \\
\hline & medium timber & 0.103 & 0.173 & 0.60 & -0.019 & 0.010 & -1.87 & & & & & & \\
\hline & large timber & 0.966 & 0.187 & 5.17 & 0.011 & 0.011 & 0.99 & & & & & & \\
\hline & mixed stages & 0.057 & 0.256 & 0.22 & 0.037 & 0.015 & 2.48 & & & & & & \\
\hline soil pH & & -0.257 & 0.053 & -4.83 & & & & & & & & & \\
\hline soil depth & & & & & & & & -0.010 & 0.003 & -3.73 & & & \\
\hline hill slope & & 0.017 & 0.005 & 3.54 & & & & & & & & & \\
\hline number of observations & & 1292 & & & 1251 & & & 874 & & & 155 & & \\
\hline number of sites & & 18 & & & 18 & & & 18 & & & 6 & & \\
\hline degrees of freedom & & 15 & & & 10 & & & 9 & & & 5 & & \\
\hline
\end{tabular}




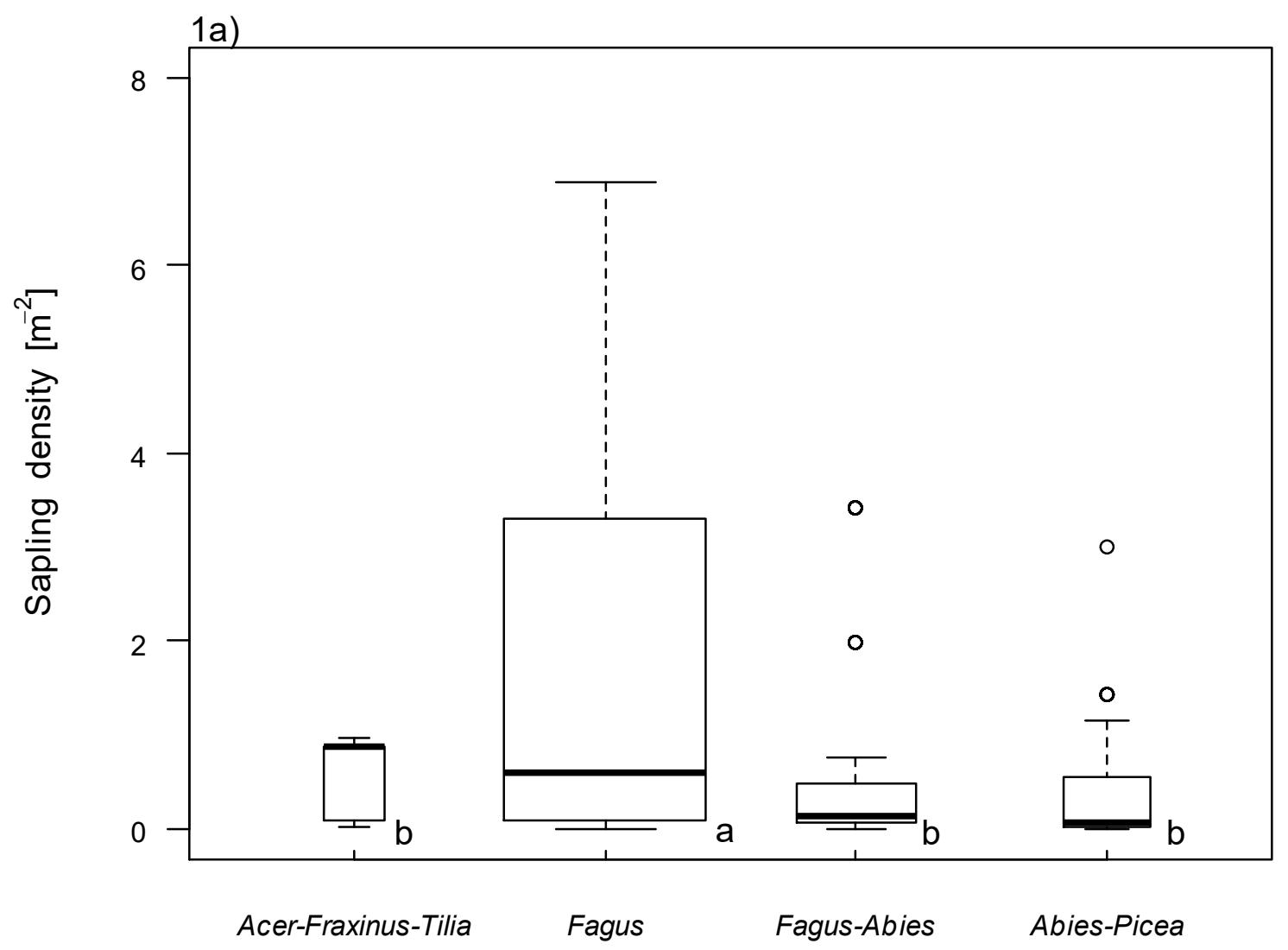

Forest type

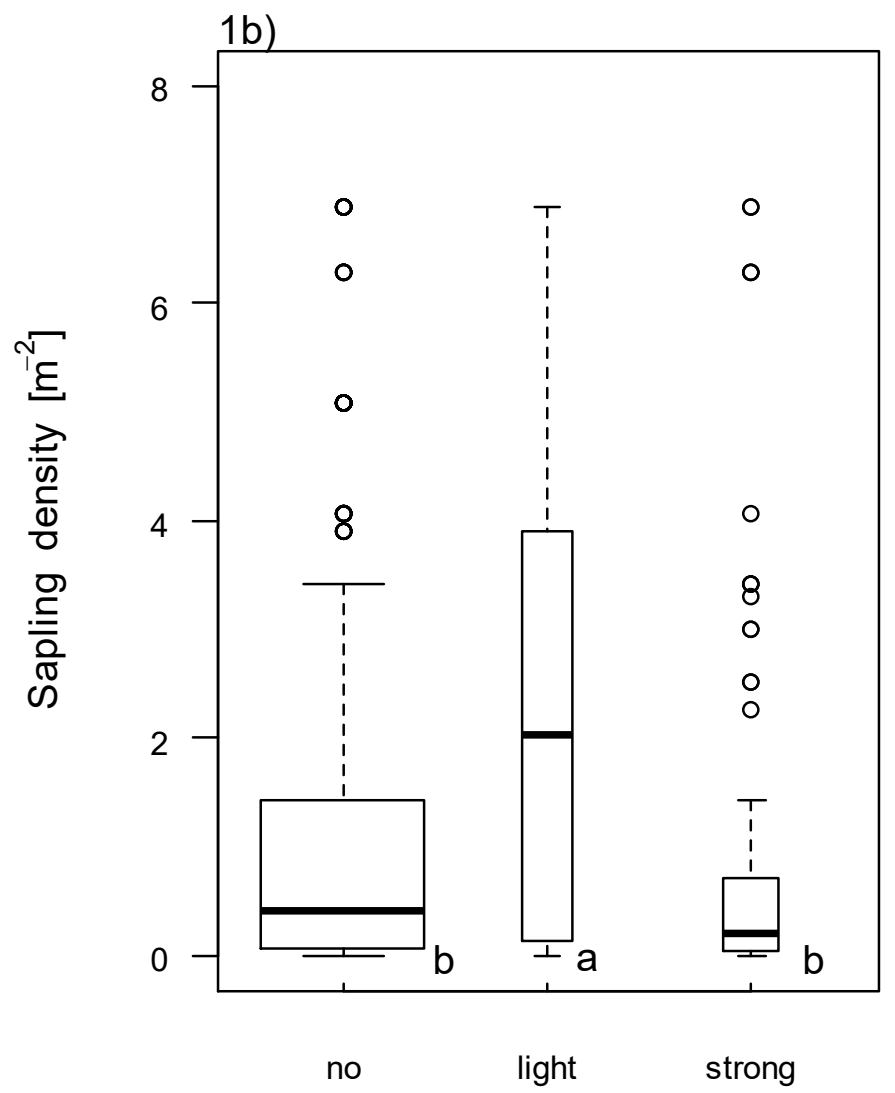

Within-tree browsing intensity

Fig. 1. Abies alba sapling density per square meter in plots that contained Abies regeneration in relation to forest type (1a) or within-tree browsing intensity of leader shoots (1b). Only the 18 sites with data collected in spring were used. Letters refer to significant differences at $P=0.01$ between the forest types or the within-tree browsing intensity in the pairwise t-tests. Median (bold line), first and third quartile (bottom and top of the box) with whiskers at quartile $\pm 1.5 *$ interquartile range and individual points more extreme in value (circles) have been drawn using boxplot in default $\mathrm{R}$ code. Extreme outliers were omitted for appropriate scaling. The width of the boxes represents the number of trees within the various categories. 


\section{Within-tree browsing intensity and growth rate of Abies alba saplings}

Overall, the relative growth rate of Abies saplings was greatest for saplings that were lightly browsed on their leader shoot in that year, followed by saplings not browsed on their leader shoot in that year. The lowest relative growth rate was observed for saplings that were strongly browsed on their leader shoot (Fig. 2a, Table 3). The fit of the statistical model was significantly lower with presence/absence of browsing used in place of within-tree browsing intensity, but it was still better than the fit of a model without a browsing-related factor (Table 2). This pattern in relative growth was independent of forest type (no significant effect of forest type (Table 2) or of the interaction term with within-tree browsing intensity $(\mathrm{AIC}=-2175))$, although this pattern tended to be less pronounced for Fagus-Abies and Picea-Abies forests, where saplings that were not browsed or lightly browsed grew equally well but unbrowsed saplings clearly grew better than strongly browsed trees (Fig. 2c).

The within-tree browsing intensity but not the growth of Abies saplings itself was influenced by forest type. This was shown by the fact that in Fagus and Acer-Fraxinus-Tilia forests more than half of the browsed Abies saplings were only lightly browsed, while in Fagus-Abies forests 2.5 times more and in Abies-Picea forests 2 times more Abies saplings were browsed strongly than lightly (\% values shown in Fig. 2c). In addition, the percentage of browsed Abies saplings was higher in Fagus (16.6\%) and Fagus-Abies forests (17.5\%) compared with in Picea-Abies (10.6\%) and Acer-Fraxinus-Tilia forests (7.1\%; Fig. 2c).

Abies saplings in stands with 'mixed stages' had a higher relative growth rate of Abies saplings than all other stand developmental stages (Fig. 2b, Table 3). No significant effect on the relative growth rate of Abies saplings was found for soil $\mathrm{pH}$, soil depth or stand basal area (Table 2). In addition, no significant interactions between within-tree browsing intensity and these variables were found. Thus, these three variables were removed from the statistical model for growth of Abies saplings (Table 3). 

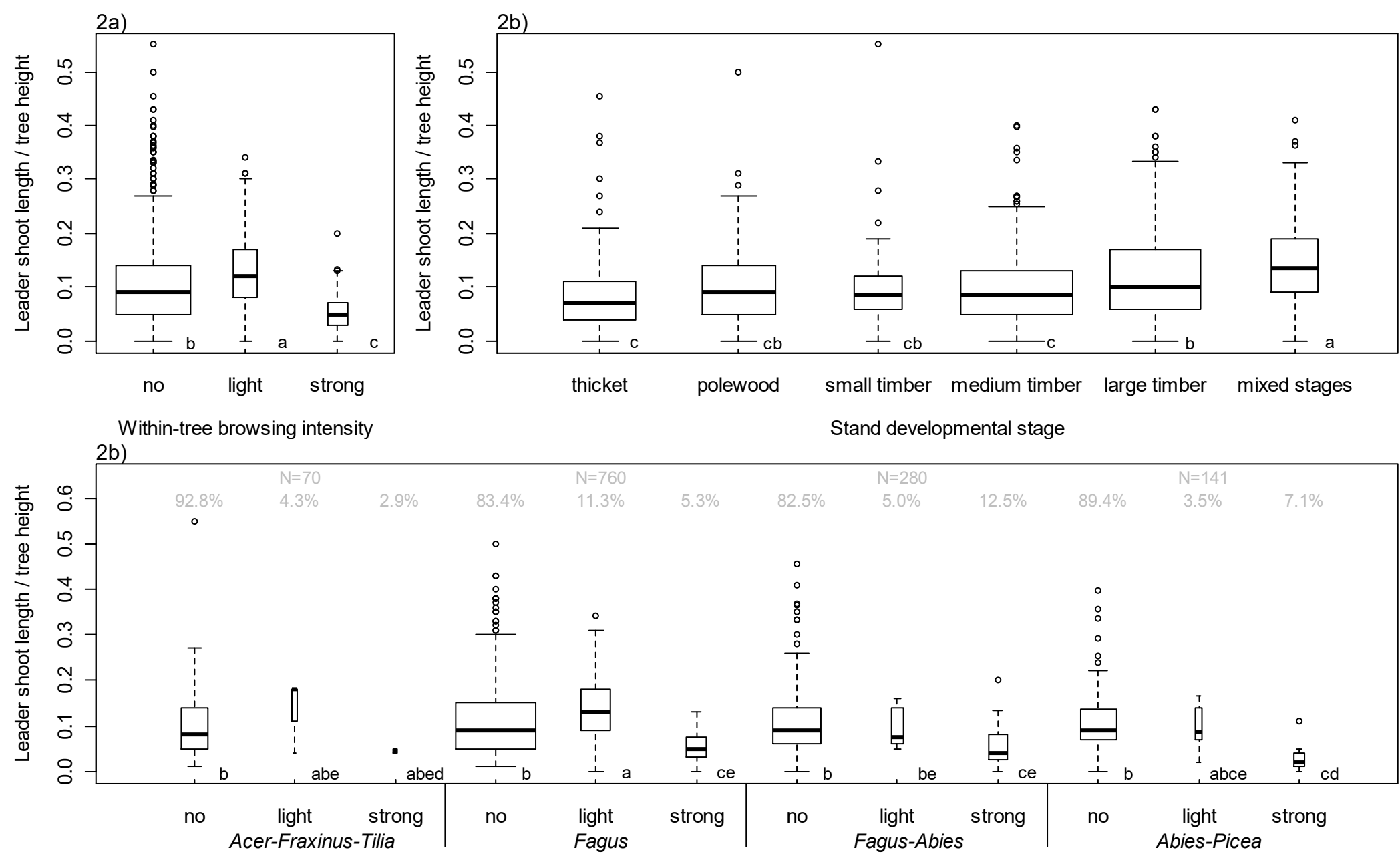

Fig. 2. Relative growth rate of Abies alba saplings in relation to within-tree browsing intensity of leader shoots (2a), stand developmental stage (2b), and $A b i e s$ alba within-tree browsing intensity (no, light or strong browsing on leader shoots) in the four different forest types (2c). Only the 18 sites with data collected in spring were used. Letters refer to significant differences at $P=0.01$ between the within-tree browsing intensities (2a) or the developmental stages (2b) and at $P$ $=0.05$ between the within-tree browsing intensities within each forest type $(2 \mathrm{c})$ in the pairwise t-tests. The number of $A b i e s$ saplings per forest type $(\mathrm{N})$ and the percentage of each within-tree browsing intensity within each forest type (\%) are given. 


\section{Within-tree browsing intensity and ratio of the relative growth rate of Abies to Picea}

In cases where the ratio of the relative growth rate of Abies saplings to the relative growth rate of Picea saplings was higher than one, the Abies sapling of the respective height class and plot was growing better than the unbrowsed Picea sapling, and in cases where the value was lower than one, the unbrowsed Picea sapling was growing better. This ratio was higher if all Abies-Picea pairs with lightly browsed Abies saplings were considered than if the unbrowsed Abies saplings were considered, which in turn was higher than if strongly browsed Abies saplings were considered (Table 3 and all sites in Fig. S2). However, there were significant differences between forest types (Table 3). For all Abies-Picea pairs, and in particular for those calculated with lightly browsed or unbrowsed Abies saplings (Fig. 3), the ratio was higher in Fagus forests than in Fagus-Abies forests, and a ratio intermediate to the values of these two forest types was found in Picea-Abies forests. When viewed in greater detail, it is apparent that lightly browsed Abies saplings in Fagus forests grew, on average, twice as well as Picea saplings and thus significantly better than unbrowsed Abies saplings in Fagus forests, while there was no statistically significant difference between the rate of relative growth of Abies to Picea saplings for lightly and unbrowsed Abies saplings in Fagus-Abies and Picea-Abies forests (Fig. 3). The ratio of the relative growth rate of unbrowsed Abies saplings to unbrowsed Picea saplings was around (Fagus-Abies forests) or higher than one (other forest types), and it always tended to be higher than rates for strongly browsed Abies saplings, though only significantly higher in Fagus forests (Fig. 3). Browsing led to a shift in the growth rate rank of Abies compared with Picea saplings, but only in cases where the within-tree browsing intensity was strong (Fig. 3).

At the single site level the overall pattern remained the same, although there were some differences. In particular, two sites dominated by Fagus forests showed similar or a tendency of less growth of pairs with lightly browsed Abies saplings compared with unbrowsed ones (i.e. Altenberg, Hofstetten) but still more growth compared with strongly browsed trees (Fig. S2).

No significant effects of or interactions between soil $\mathrm{pH}$, stand basal area and stand developmental stage in relation to the ratio of the relative growth rate of Abies to Picea saplings were found (Table 2). However, soil depth significantly increased the model goodness of fit (Table 2). On the one hand, soil depth may represent differences between Fagus-Abies and Abies-Picea forest types. Soil was shallower in Fagus-Abies forests than in Abies-Picea forests, in particular in plots with pairs containing browsed Abies saplings (Fig. 4). On the other hand, when the soil within every individual forest type were compared, shallower soil tended to be associated with light browsing but no clear pattern could be detected (Fig. 4).

Regarding the growth ratio of Abies saplings one year after browsing (measurements completed in autumn 2015), Abies saplings in pairs with previously lightly browsed Abies saplings grew better than those in pairs with unbrowsed Abies saplings and often also grew better than those in pairs with strongly browsed Abies saplings (Fig. 5, Table 3). This finding indicates that lightly browsed Abies saplings have higher growth rates, not only in the year they are browsed (Fig. 3 and all sites in Fig. S2), but also in the successive year (Fig. 5). 


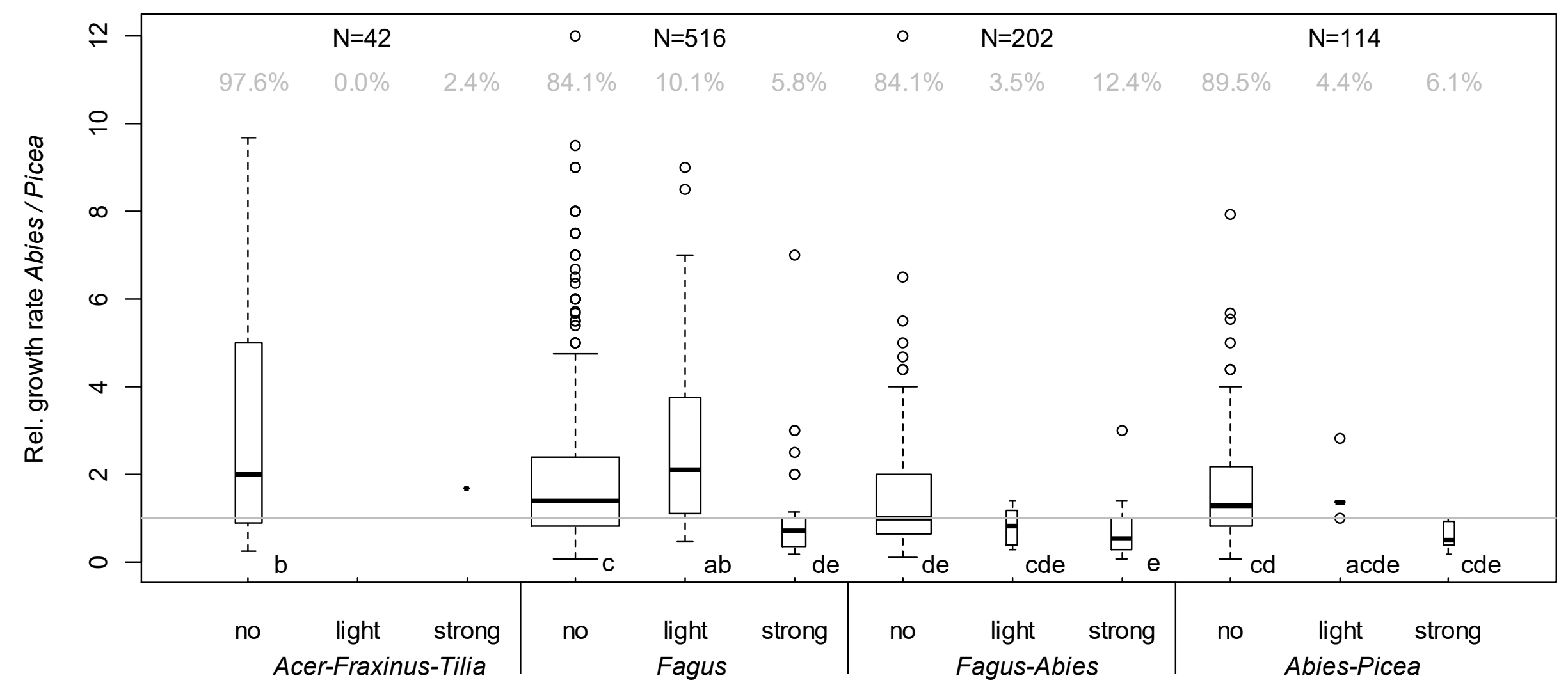

Fig. 3. Ratio of the relative growth rate of Abies alba saplings to the relative growth rate of unbrowsed Picea abies saplings of the same height class from the same plot in relation to Abies alba within-tree browsing intensity (no, light or strong browsing on leader shoots) for each forest type. The grey line indicates equal growth of Abies and Picea saplings in the plot. Only the 18 sites with data collected in spring were used. The number of pairs per forest type ( $N$ ) and the percentage of each within-tree browsing intensity within each forest type (\%) are given. Letters refer to significant differences at $P=0.05$ in the pairwise t-tests. 

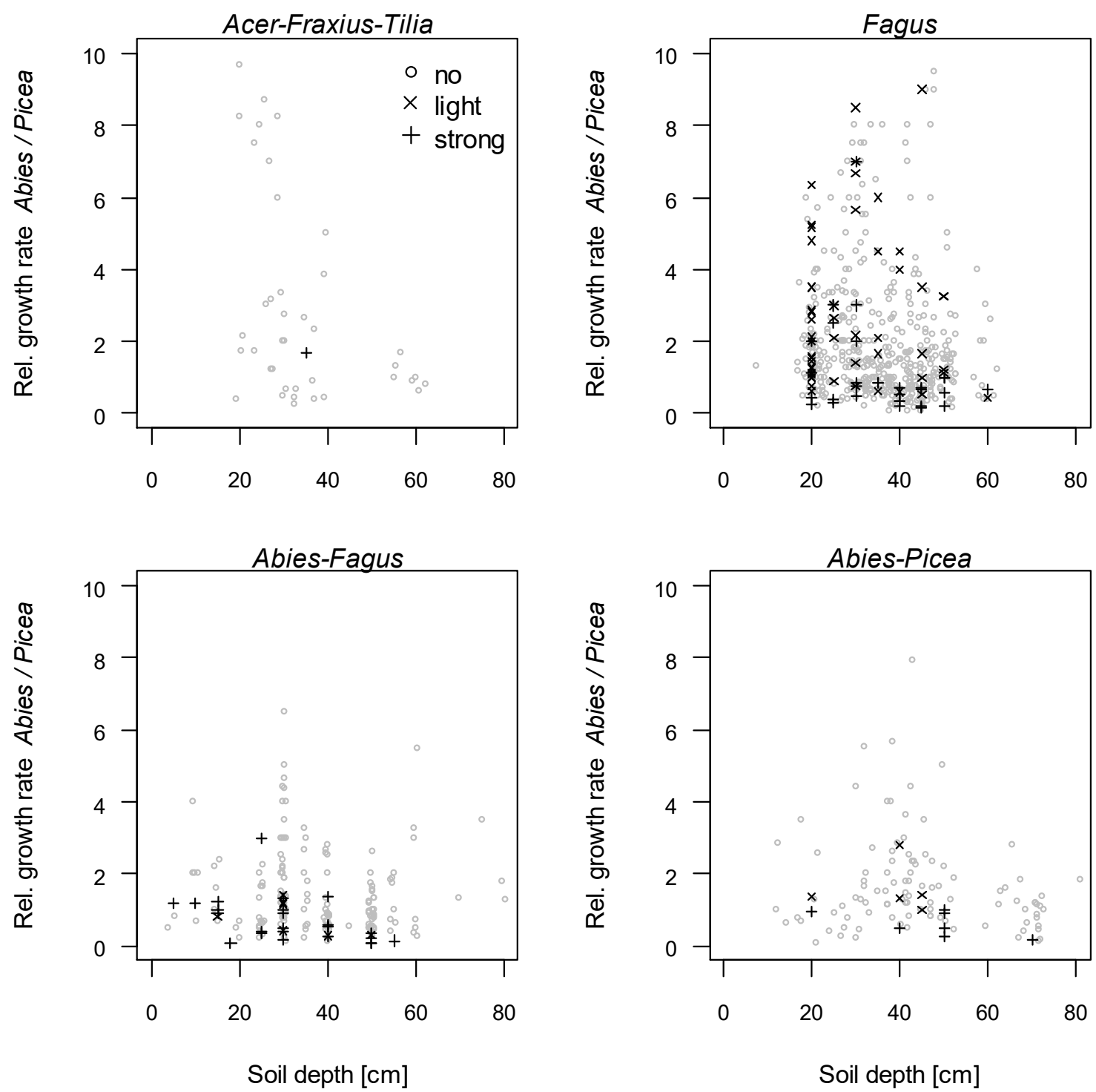

Fig. 4. Ratio of the relative growth rate of Abies alba saplings to the relative growth rate of unbrowsed Picea abies saplings of the same height class from the same plot in relation to Abies alba within-tree browsing intensity (no, light or strong browsing on leader shoot) along the soil depth gradient for each of the four forest types. For a better overview, a slight irregular movement of max $3 \mathrm{~cm}$ was added to soil depth values (function jitter() in R). 

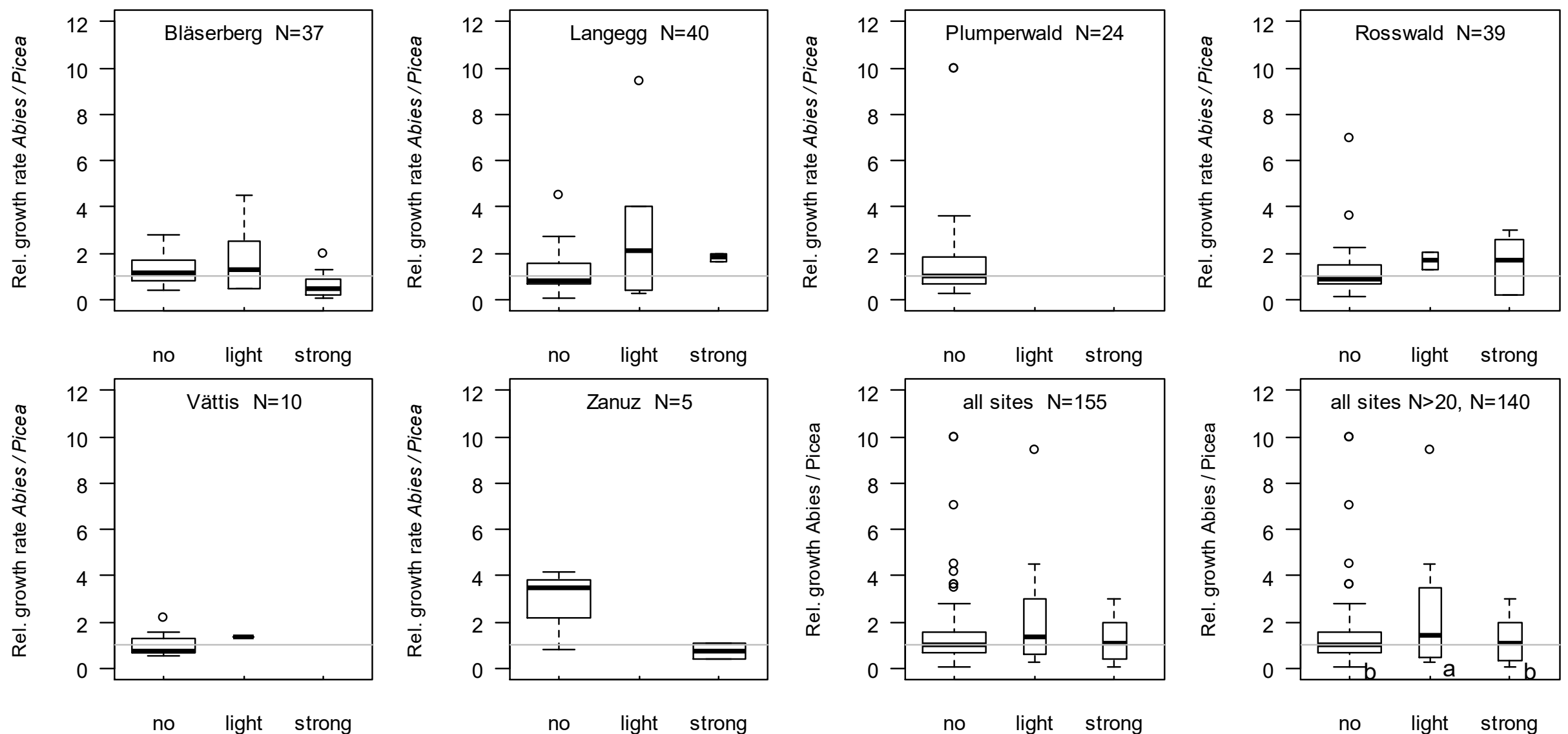

Fig. 5. Ratio of the relative growth rate of Abies alba saplings to the relative growth rate of Picea abies saplings of the same height class from the same plot in relation to Abies alba within-tree browsing intensity in the preceding winter (no, light or strong browsing on leader shoots). Grey lines indicate equal growth of Abies and Picea saplings in the plot. Only the six sites with data collected in autumn 2015 were used, and in the last panel only sites with $\mathrm{N}>20$ trees were considered. $\mathrm{N}=$ the number of pairs within each site. Letters refer to significant differences at $P=0.05$ in the pairwise t-tests. 


\section{Discussion}

The growth of Abies alba saplings with different degrees of leader shoot browsing (within-tree browsing intensity) were compared among four major forest types in Switzerland. In the absence of browsing, the relative growth rate of Abies saplings did not differ among forest types. However, lightly browsed Abies saplings were more frequent in Fagus-dominated forests than in Fagus-Abies or Abies-Picea forests. This finding is particularly important because lightly browsed Abies saplings had no growth losses compared with unbrowsed trees. In contrast, strongly browsed Abies saplings clearly grew less than unbrowsed trees. For example, in Fagus forests an average of $16.6 \%$ of the Abies saplings were browsed (defined as 'browsing intensity', Berwert-Lopes, 1996), but only 5.3\% of the Abies saplings were strongly browsed and these effectively suffered from a browsing impact. In addition, sapling density was higher in such Fagus forests, as also found in other studies (Kramer et al., 2014), and the overall impact of a similar proportion of browsed trees was much lower in Fagus compared with in Fagus-Abies or Abies-Picea forests. This finding would not have been revealed if only the presence or absence of browsing was taken into account.

The importance of within-tree browsing intensity for Abies sapling growth was even more pronounced than that of forest type, as lightly browsed Abies saplings grew better than unbrowsed saplings in the year of browsing and also in the season after browsing. Generally, conspicuous tree saplings that stand out from the other vegetation are more likely to be browsed than partially obscured plants (Kupferschmid et al., 2015b; Miller et al., 1982). For example, dominant Picea abies saplings in a regeneration cluster were browsed more often than other trees in the cluster (Näscher, 1979). If the morphologically dominant trees, i.e. the most vigorously growing trees, are more often browsed (Häsler and Senn, 2012; lason et al., 1996) but, perhaps owing to the presence of more saplings, only lightly (i.e. only leader bud removal), then even repeatedly browsed Abies saplings can continue to grow faster than unbrowsed and otherwise suppressed ones (Kupferschmid et al., 2013). In this case, I would expect to find i) a higher frequency of lightly than strongly browsed saplings, ii) a higher relative growth rate of lightly browsed than unbrowsed or strongly browsed saplings, and iii) no shift in the relative difference in growth rates between species. This coincides with what I found in most of the assessed Fagus forests, where there was no detectable shift in the growth rate rank between Abies and Picea saplings (Fig. 3). As it is typically desirable to maintain the most vigorous trees in forests that are managed for timber, such selection by ungulates may have the important impact of reducing the potential timber value of a stand (Edenius et al., 2002; Wallgren et al., 2014).

If, however, the most vigorously growing trees are browsed at a higher frequency and with a greater quantity of material removed (Hartley et al., 1997), it is likely that their status will change over time and that ungulates will subsequently select previously unbrowsed trees (Duncan et al., 1998). This tendency may lead to only the least vigorous trees remaining, resulting in an underestimation of the real height growth rate of tree saplings (Bergquist et al., 2003). In contrast to the effects of light browsing by ungulates, strong browsing on vigorously growing saplings may therefore lead to shifts in the relative rates of growth of different tree species, as was the case in the assessed Fagus-Abies and Abies-Picea forests (Fig. 3). Such an ungulate-induced species shift has also been found in many other forest types (e.g. Tripler et al., 2005). For example, birch saplings grew better than beech without browsing, but vice versa with browsing, as beech sapling growth was not reduced by herbivory (Krueger et al., 2009). Species that are resistant to browsing can have a competitive advantage and this can shift forest composition, e.g. from Abies balsamea to Picea spp. (Tremblay et al., 2007) or from Nothofagus spp. to Pseudowintera colorata (Husheer et al., 2003).

In the majority of cases, the degree of growth loss and stem deformation, as well as the likelihood of death, caused by browsing increases with the severity of browsing (Gill, 1992b; Wallgren et al., 2014). As solitary (and in particular planted) tree saplings are more likely to be browsed than densely regenerated recruitments (Čermák et al., 2009; Reimoser and Gossow, 1996; van Beeck Calkoen et al., 2018) and are probably also more severely browsed, the mortality induced by ungulate browsing 
may prevent the upgrowth of such saplings (Kupferschmid et al., 2014). The apparently relatively low number of Abies saplings, and in particular of browsed Abies saplings, in the assessed Fagus-Abies and Abies-Picea forests may thus be the result of a combination of overall poor regeneration conditions and high browsing-induced mortality. Within-tree browsing intensity could serve to distinguish between light and strong browsing of vigorously growing trees; further, in the case of strong browsing, this variable suggests that a higher browsing-induced mortality rate could mask an underlying higher browsing percentage. Thus, within-tree browsing intensity would therefore be a much better estimator of the current ungulate impact than the commonly used proportion of browsed trees.

Site characteristics define the availability of resources such as nutrients, water and light, and thus have a large impact on the establishment, growth and mortality of tree saplings and other vegetation. Apart from forest type, stand developmental stage, $\mathrm{pH}$ of the soil A-horizon and hill slope affected the observed Abies sapling density (Table 3), i.e. the establishment rate of Abies alba. In contrast to findings from an analysis of windthrow sites in Switzerland (Kramer et al., 2014), higher $\mathrm{pH}$ values were associated with lower sapling density overall (cf. Table 3 ) and in each individual forest type (no significant interaction term). A confounding effect of forest type can therefore be excluded in my study. As the availability of nutrients and the concentration of nutrients in the Abies saplings are related to soil pH, $\mathrm{pH}$ generally has an influence on Abies sapling growth (Entry et al., 1987). However, in my study soil pH had no influence on the growth of Abies saplings and also no effect on the within-tree browsing intensity. Jensen et al. (2011) found no difference in soil pH between Tsuga canadensis stands with high deer-use and low deer-use. Perhaps in field surveys an influence of $\mathrm{pH}$ is masked by other site characteristics such as soil depth. Indeed, in my study, deeper soil was associated with less growth of Abies saplings in relation to the growth of Picea saplings (Table 3). As ungulates select the most vigorously growing trees (Price, 1991), the attractiveness of Abies for browsing should thus tend to be lower in deeper soils. Browsing incidence did not vary along the gradient of soil depth, although somewhat shallower soils tended to be associated with light browsing (Fig. 4). The exact relationship between soil depth or $\mathrm{pH}$ and the within-tree browsing intensity needs to be investigated more closely.

More Abies saplings were observed in stands with large timber trees, but a higher relative growth rate of Abies saplings was measured in mixed-stage stands. Stand basal area, which can be interpreted as a further proxy for light, had a significant influence on neither Abies sapling density nor Abies growth. These results indicate the high shade tolerance of Abies alba saplings (i.e. Landold indicator value of 1 , see Lauber and Wagner, 1996). In addition, no interaction of stand developmental stage or stand basal area with within-tree browsing intensity was found, which suggests no general effect of light on within-tree browsing intensity.

Growth and mortality are not the only variables that are affected by browsing. In tree species with strong apical dominance, anomalies in stem structure can result from browsing (Gill, 1992b). Such changes in stem structure can appear even after leader bud removal, i.e. light browsing, owing to the loss of apical dominance. Formerly dormant meristems resume growth following the damage to the shoot apex (Aarssen, 1995), resulting in bushy and/or multi-stemmed trees (Kupferschmid and Bugmann, 2013; Strauss and Agrawal, 1999). However, the influence on tree quality has generally been found to be larger after strong, and in particular after repeated, browsing (Eiberle, 1978; Wallgren et al., 2014).

To conclude, within-tree browsing intensity influences i) the growth of Abies alba saplings, ii) the ratio of the relative growth rate of saplings of Abies alba to saplings of Picea abies, leading to shifts in the growth ranking of different tree species, and iii) depends on forest type and probably also soil depth. Thus, within-tree browsing intensity is an informative indicator with regard to browsing impact that should be incorporated into future browsing inventories. 


\section{Acknowledgements}

I am grateful to the cantonal authorities for providing GIS data on forest types and to the local foresters for their competent assistance during field assessments in their forest districts. I would like to thank several trainees and students for their help with field work. M. Dawes is gratefully acknowledged for providing linguistic suggestions. The work was funded by the Federal Office for the Environment FOEN as part of the project 'Herleitung von Merkmalen zur Beurteilung des Wildeinflusses auf die Waldverjüngung', contract No. 00.01 38.PZ / N433-1185 (extension: No. 00.0138.PZ / P474-0938).

\section{Supplementary material}

Fig. S1: Abies alba sapling density in relation to stand developmental stage.

Fig. S2: Relative growth rate of Abies alba saplings in relation to within-tree browsing intensity of leader shoots for individual sites.

\section{References}

Aarssen LW. Hypotheses for the evolution of apical dominance in plants: implications for the interpretation of overcompensation. OIKOS (1995) 74:149-156.

Amt für Wald Graubünden. Erhebung von Jungwuchs und Schäden durch Wild (2005) Chur. 4.

Augustine DJ, McNaughton SJ. Ungulate effects on the functional species composition of plant communities: hervivore selectivity and plant tolerance. J. Wildl. Manage. (1998) 62:11651183.

Bates D, Maechler M, Bolker B, Walker S. Fitting Linear Mixed-Effects Models Using Ime4. J. Stat. Softw. (2015) 67:1-48.

Bergquist J, Bergström R, Zakharenka A. Responses of young Norway spruce (Picea abies) to winter browsing by roe deer (Capreolus capreolus): Effects on height growth and stem morphology. Scand. J. For. Res. (2003) 18:368 - 376.

Berwert-Lopes R. Assessment of tolerable browsing by Eiberle's method: Limitations and future prospects. For. Ecol. and Manage. (1996) 88:87-91.

Bitterlich W. The Relascope Idea. (1984) Farnham: Commonwealth Agricultural Bureaux.

Boulanger V, Baltzinger C, Sal S, Ballon P, Picard J-F, Dupouey J-L. Ranking temperate woody species along a gradient of browsing by deer. For. Ecol. and Manage. (2009) 258:1397-1406.

Čermák $\mathrm{P}$, Horsák $\mathrm{P}$, Špiřík M, Mrkva R. Relationships between browsing damage and woody species dominance. J. For. Sci. (2009) 55:23-31.

Cornelis J, Casaer J, Hermy M. Impact of season, habitat and research techniques on diet composition of roe deer (Capreolus capreolus): a review. J. Zool. (1999) 248:195-207.

Coté SD, Rooney TP, Tremblay J-P, Dussault C, Waller DM. Ecological impacts of deer overabundance. Annu. Rev. Ecol. Evol. Syst. (2004) 35:113-147.

Danell K, Bergström R, Edenius L. Effects of large mammalian browsers on architecture, biomass, and nutrients of woody plants. J. Mammal. (1994) 75:833-844.

Didion $M$, Kupferschmid $A D$, Bugmann $H$. Long-term effects of ungulate browsing on forest composition and structure. For. Ecol. and Manage. (2009) 258:44-55.

Didion $\mathrm{M}$, Kupferschmid AD, Wolf A, Bugmann $\mathrm{H}$. Ungulate herbivory modifies the effects of climate change on mountain forests. Clim. Chang. (2011) 109:647-669.

Duncan AJ, Hartley SE, lason GR. The effect of previous browsing damage on the morphology and chemical composition of Sitka spruce (Picea sitchensis) saplings and on their subsequent 
susceptibility to browsing by red deer (Cervus elaphus). For. Ecol. and Manage. (1998) 103:57-67.

Edenius L, Bergman M, Ericsson G, Danell K. The role of moose as a disturbance factor in managed boreal forests. Silva Fenn. (2002) 36:57-67.

Eiberle K. Folgewirkungen eines simulierten Wildverbisses auf die Entwicklung junger Waldbäume. Schweiz. Z. Forstwes. (1978) 129:757-768.

Entry JA, Cromack K, Stafford SG, Castelland MA. The effect of $\mathrm{pH}$ and aluminum concentration on ectomycorrhizal formation in Abies balsamea. Can. J. For. Res. (1987) 17:865-871.

Gill RMA. A review of damage by mammals in north temperate forests: 1 . Deer. Forestry (1992a) 65:145-169.

Gill RMA. A review of damage by mammals in North Temperate forests: 3. Impact on trees and forests. Forestry (1992b) 65:363-388.

Gill RMA, Beardall V. The impact of deer on woodlands: the effects of browsing and seed dispersal on vegetation structure and composition. Forestry (2001) 74:209-218.

Hartley SE, lason GR, Duncan AJ, Hitchcock D. Feeding behaviour of red deer (Cervus elaphus) offered sitka spruce saplings (Picea sitchensis) grown under different light and nutrient regimes. Funct. Ecol. (1997) 11:348-357.

Häsler H, Senn J. Ungulate browsing on silver fir: the role of occasions, food shortage, and diet preferences Wildl. Biol. (2012) 18:67-74.

Husheer SW, Coomes DA, Robertson AW. Long-term influences of introduced deer on the composition and structure of New Zealand Nothofagus forests. For. Ecol. and Manage. (2003) 181:99-117.

Iason GR, Duncan AJ, Hartley SE, Staines BW. Feeding behaviour of red deer (Cervus elaphus) on sitka spruce (Picea sitchensis): the role of carbon-nutrient balance. Forest Ecology and Management (1996) 88:121-129.

Jensen NR, Webster CR, Witt JC, Grant JB. Ungulate winter habitat selection as a driver of herbaceous-layer heterogeneity in northern temperate forests. Ecosphere (2011) 2.

Kleinn C, Vilčko F, Fehrmann L, Hradetzky J. Zur Auswertung der k-Baum-Probe. [About the evaluation of k-trees samples]. . Allg. Forst. Jagdz. (2009) 180:228-237.

Kramer K, Brang P, Bachofen H, Bugmann H, Wohlgemuth T. Site factors are more important than salvage logging for tree regeneration after wind disturbance in Central European forests. For. Ecol. and Manage. (2014) 331.

Krueger LM, Peterson CJ, Royo A, Carson WP. Evaluating relationships among tee growth rate, shade tolerance, and browse tolerance following disturbance in an eastern deciduous forest. Can J For Res (2009) 39:2460-2469.

Kupferschmid AD. Compensation capacity of Central European tree species in response to leader shoot browsing. In: Ungulates: evolution, diversity and ecology--Menendez A, Sands N, eds. (2017) Hauppauge, USA: Nova Science Publishers. 1-63.

Kupferschmid AD, Brang P. Praxisrelevante Grundlagen: Zusammenspiel zwischen Wild und Wald. In: Wald und Wild - Grundlagen für die Praxis. Wissenschaftliche und methodische Grundlagen zum integralen Management von Reh, Gämse, Rothirsch und ihrem Lebensraum (2010) Bern: Bundesamt für Umwelt BAFU. 9-39.

Kupferschmid AD, Bugmann $\mathrm{H}$. Timing, light availability and vigour determine the response of Abies alba saplings to leader shoot browsing. Eur. J. For. Res. (2013) 132:47-60.

Kupferschmid $A D$, et al. Einfluss wildlebender Huftiere auf die Waldverjüngung: ein Überblick für die Schweiz. Schweiz. Z. Forstwes. (2015a) 166:420-431.

Kupferschmid AD, Wasem $\mathrm{U}$, Bugmann $\mathrm{H}$. Light availability and ungulate browsing determine growth, height and mortality of Abies alba saplings. For. Ecol. and Manage. (2014) 318:359-369.

Kupferschmid AD, Wasem $U$, Bugmann $\mathrm{H}$. Ungulate browsing leads to height and diameter growth reduction on Abies alba saplings planted along light gradients. Eur. J. For. Res. (2015b) 134:75-87. 
Kupferschmid AD, Zimmermann S, Bugmann H. Browsing regime and growth response of naturally regenerated Abies alba saplings along light gradients. For. Ecol. and Manage. (2013) 310:393-404.

Lauber K, Wagner G. Flora Helvetica. (1996) Bern: Verlag Paul Haupt.

Miller GR, Kinnaird JW, Cummins RP. Liability of saplings to browsing on a red deer range in the Scottish Highlands. J. Appl. Eclol. (1982) 19:941-951.

Näscher FA. Zur waldbaulichen Bedeutung des Rothirschverbisses in der Waldgesellschaft des subalpinen Fichtenwalds in der Umgebung des schweizerischen Nationalparks. In: Abteilung für Forstwirtschaft, Waldbau (1979) Zürich: ETH Zürich. 120.

Price PW. The plant vigor hypothesis and herbivore attack. OIKOS (1991) 62:244-251.

R Core Team. R: A language and environment for statistical computing. (2016) Vienna, Austria: R Foundation for Statistical Computing, http://www.R-project.org.

Reimoser F, Gossow H. Impact of ungulates on forest vegetation and its dependence on the silvicultural system. For. Ecol. and Manage. (1996) 88:107-119.

Rüegg D, Nigg H. Mehrstufige Verjüngungskontrollen und Grenzwerte für die Verbissintensität. Schweiz. Z. Forstwes. (2003) 154:314-321.

Shipley LA, Illius AW, Danell K, Hobbs NT, Spalinger DE. Predicting bite size selection of mammalian herbivores: a test of a general model of diet optimization. OIKOS (1999) 84:55-68.

Stauffer HB. Contemporary bayesian and frequentist statistical research methods for natural resource scientists. (2008) Hoboken, New Jersey: John Wiley \& Sons. Inc.

Strauss SY, Agrawal AA. The ecology and evolution of plant tolerance to herbivory. Trends Evol. Ecol. (1999) 14:179-185.

Tixier H, Duncan P, Scehovic J, Yant A, Gleizes M, M. L. Food selection by European roe deer (Capreolus capreolus): effects of plant chemistry, and consequences for the nutritional value of their diets. J. Zool. (1997) 242:229-245.

Tremblay J-P, Huot J, Potvin F. Density-related effects of deer browsing on the regeneration dynamics of boreal forests. J. Appl. Ecol. (2007) 44:552-562.

Tripler CE, Canham CD, Inouye RS, Schnurr JL. Competitive hierarchies of temperate tree species: Interactions between resource availability and white-tailed deer. Ecoscience (2005) 12:494505.

van Beeck Calkoen STS, Kuijper DPJ, Sand H, Singh NJ, van Wieren SE, Cromsig JPGM. Does wolf presence reduce moose browsing intensity in young forest plantations? Ecography (2018) 41: $1-12$.

Vandenberghe $C$, Freléchoux F, Buttler A. The influence of competition from herbaceous vegetation and shade on simulated browsing tolerance of coniferous and deciduous saplings. OIKOS (2008) 117:415-423.

Wallgren M, Bergquist J, Bergström R, Eriksson S. Effects of timing, duration, and intensity of simulated browsing on Scots pine growth and stem quality. Scan. J. For. Res. (2014) 29:734746.

Wise MJ, Abrahamson WG. Beyond the compensatory continuum: environmental resource levels and plant tolerance of herbivory. OIKOS (2005) 109:417-428. 


\title{
Supplementary material
}

\section{Selective browsing behaviour of ungulates influences the}

\author{
growth of Abies alba differently depending on forest type
}

\author{
Andrea Doris Kupferschmid
}

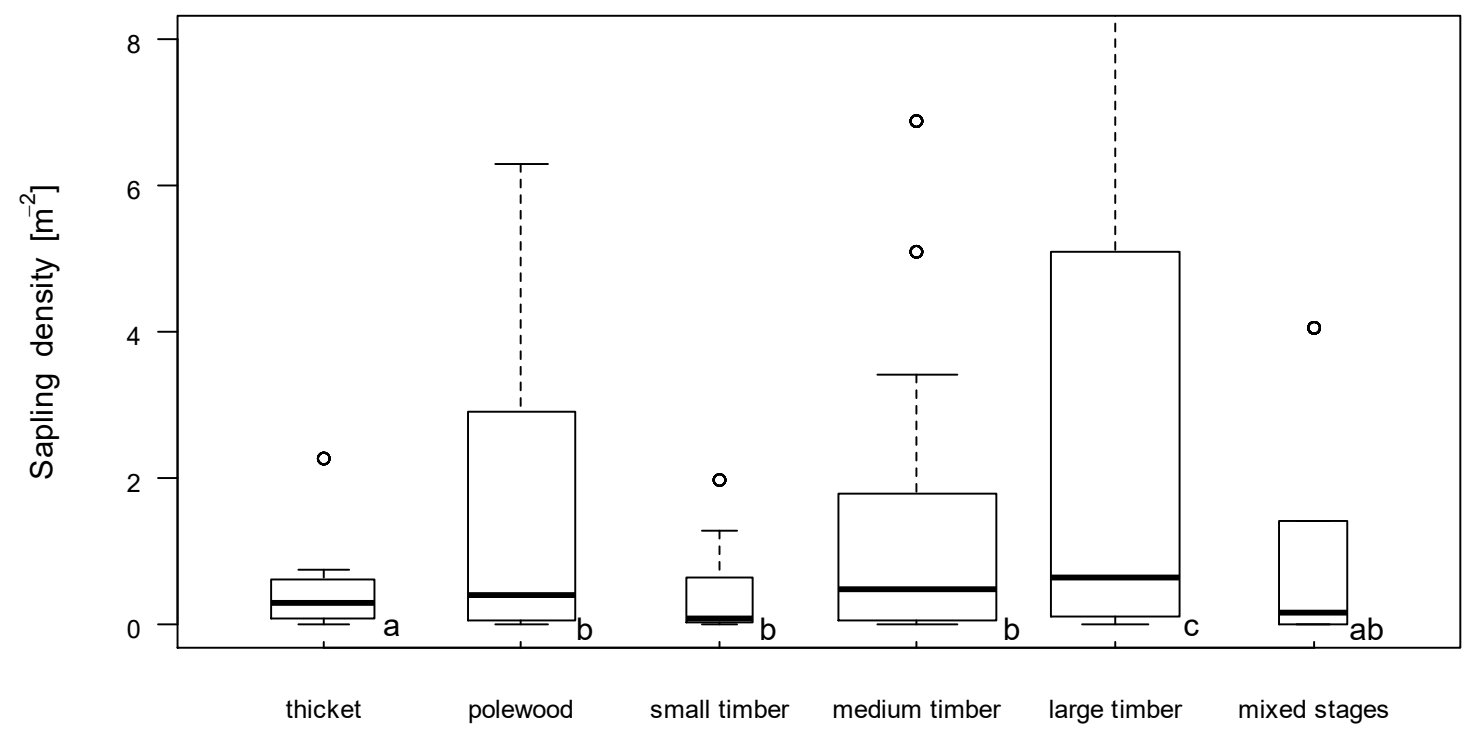

Fig. S1 Abies alba sapling density per square meter in plots that contained Abies regeneration in relation to stand developmental stage. Only the 18 sites with data collected in spring were used. Letters refer to significant differences at $P=0.01$ between the developmental stages in the pairwise $\mathrm{t}$ tests. Median (bold line), first and third quartile (bottom and top of the box) with whiskers at quartile $\pm 1.5^{*}$ interquartile range and individual points more extreme in value (circles) have been drawn using boxplot in default $\mathrm{R}$ code. Extreme outliers were omitted for appropriate scaling. The width of the boxes represents the number of trees within the factor categories. 

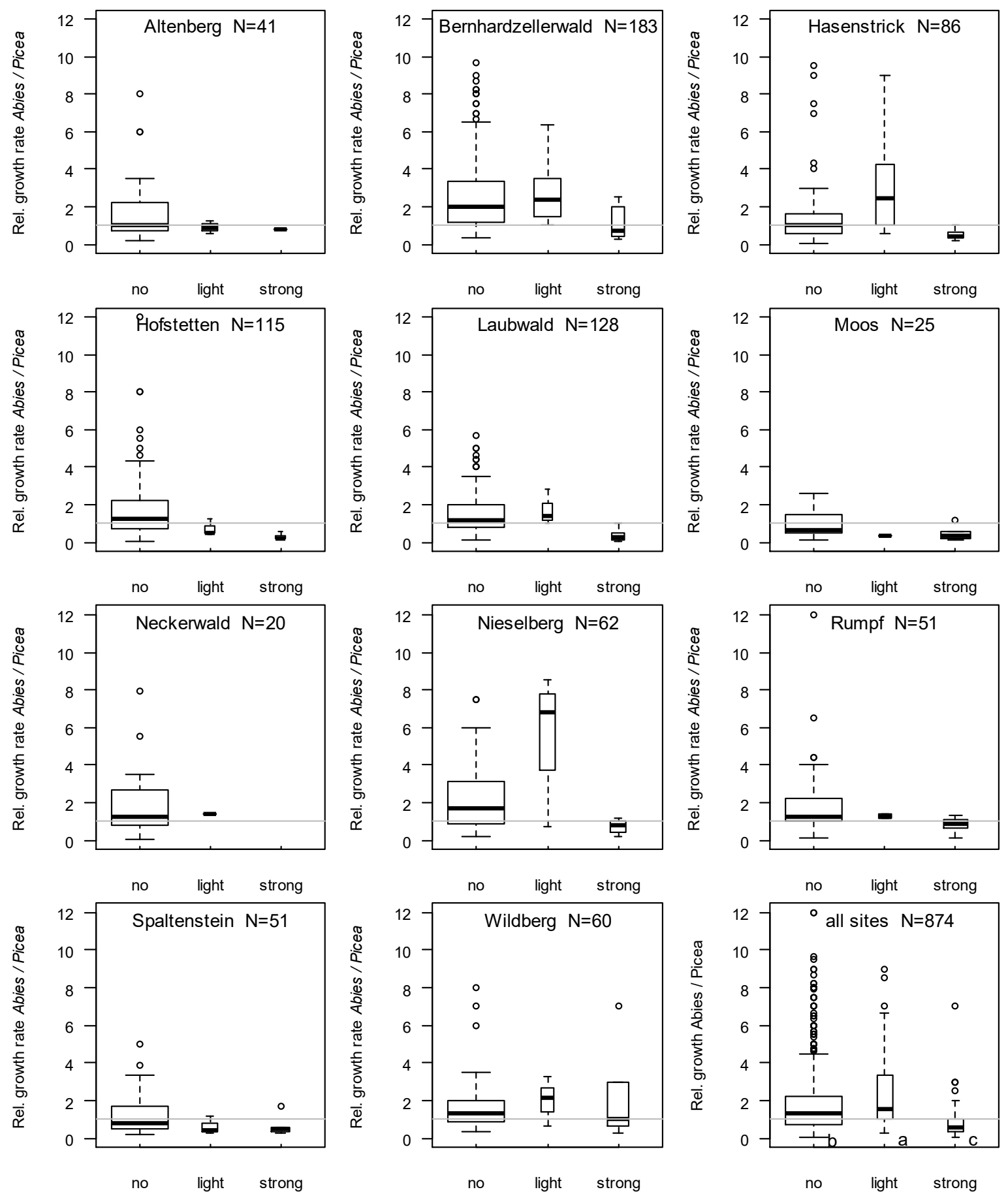

Fig. S2 Ratio of relative growth rate of Abies alba saplings to relative growth rate of Picea abies saplings of the same height class from the same plot in relation to Abies alba within-tree browsing intensity (no, light or strong browsing on leader shoot) for each site with more than 20 pairs of AbiesPicea. $\mathrm{N}=$ the number of pairs within each site. Grey lines indicate equal growth of Abies and Picea saplings in the plot. 